\title{
Minyak Atsiri untuk Konservasi Cagar Budaya Berbahan Batu Tahap II
}

\author{
Sri Wahyuni, Winda Diah Puspita Rini, Bambang Kasatriyanto, \\ Al Widyo Purwoko, Basuki Rachmat, \\ Balai Konservasi Borobudur \\ Email : nyun2_euro@yahoo.com
}

\begin{abstract}
Abstrak : Lumutkerak/lichen merupakan salah satu mikroorganisme yang dapat mengakibatkan kerusakan dan pelapukan pada Cagar Budaya berbahan batu. Bahan kimia AC 322 selama ini merupakan satu-satunya bahan yang digunakan untuk mengatasi permasalahan lumut kerak yang menempel pada permukaan batu. Oleh sebab itu perlu dicari bahan alternatif yang dapat digunakan untuk mengatasi lumut kerak/ lichen. Pengembangan metode dan teknik konservasi berbahan tradisional mulai banyak dikembangkan.

Bahan tradisional banyak sekali ditemui di alam. Salah satunya adalah minyak atsiri yang dapat digunakan sebagai pestisida alami untuk mengatasi permasalahan lumut kerak/lichen. Pada tahun 2014, Balai Konservasi Borobudur bekerjasama dengan UniversitasIslam Indonesia dalam rangka penanganan lumut kerak menggunakan minyak atsiri. Minyak atsiri yang digunakan dalam penelitian adalah minyak atsiri cengkeh, minyak biji pala dan minyak serai wangi.Tahun 2015 juga dilakukan kajian terhadap penggunaan minyak atsiri nilam, temulawak, dan terpentin untuk menghambat pertumbuhan lumut kerak pada Cagar Budaya batu andesit. Percobaan yang telah dilakukan pada tahun 2014 dan 2015 hanya terbatas pada pengujian daya hambat pertumbuhan jamur. Mengingat lumut kerak merupakan simbiosis antara jamur dan alga, maka perlu dilakukan uji coba minyak atsiri untuk menghambat pertumbuhan mikroalga. Kajian lanjutan pada tahun 2016, dilakukan pengujian minyak atsiri sebagai bahan untuk menghambat pertumbuhan sel mikroalga. Minyak atsiri yang digunakan adalah minyak atsiri temulawak, nilam, pala dan cengkeh.

Metode percobaan pengujian efektifitas minyak atsiri untuk menghambat pertumbuhan sel mikroalga dilakukan secara mikroskopis dengan melihat perubahan morfologi perubahan warna kloroplas dalam durasi waktu $0,3,5,7,10,15$ hari dandilakukan pengamatan jumlah mortalitas sel mikroalga durasi waktu $0,3,15$ hari. Pengamatan terhadap parameter perubahan morfologi warna kloroplas atau peluruhan warna kloroplas secara mikroskopis dilakukan dengan menggunakan mikroskop dengan perbesaran 1000x. Sedangkan penghitungan kerapatan sel, mortalitas sel mikroalga dapat dilakukan dengan menggunakan metode kamar hitung Improved Neubauer. Variasi konsentrasi minyak atsiri adalah 10\%, 20\%, 30\%, 40\% dan 50\%. Hasil pengujian menunjukkan bahwa keempat minyak atsiri dapat menghambat pertumbuhan sel mikroalga dengan tingkat keefektifan temulawak $>$ pala $>$ nilam >cengkeh. Minyak atsiri temulawak konsentrasi 20\% dengan waktu pengujian 15 hari menunjukkan daya hambat yang paling efektif dalam menghambat pertumbuhan sel mikroalga dengan mortalitas sel sebesar $63,31 \%$.
\end{abstract}

Kata kunci : mikroalga, lumut kerak, minyak atsiri

Abstract : Lichen is a microorganism that can cause damage and weathering stone material on cultural heritage. AC 322 chemicals is the only material that used to overcome the problems of lichen clinging on the stone surface. Therefore, it is necessary to find other alternative materials that can be used to treat lichen. Development of method and conservationtechniques of traditional material ranging widely developed.

Traditional materials found a lot of various in the earth, one of the essential oils that can be used as a natural pesticide to overcome the problems of lichens. In 2014, Borobudur Conservation Office collaboration with the Islamic Indonesia University startresearching of lichen treatment using essential oils. The essential oils used in this research are essential oil cloves, nutmeg and citronella. Essential oils are widely available in nature and a wide range of essential oils have been widely used as an antifungal. In 2015 also conducted a study use essential oil of patchouli, ginger, and terpentine to inhibit the growth of lichens on the stone material cultural heritage. Experiment in 2014 until 2015 only limited testing of the inhibition the growth of fungi. Given the lichen is a symbiosis between fungi and algae, it is necessary for the essential oils tested inhibited the growth of microalgae. Advanced study in 2016, conducted testing essential oils as ingredients to inhibit growth of cell microalgae. Essential oils used are essential oils of ginger, patchouli, nutmeg, and cloves.

Experiments methods done by testing the effectiveness of essential oils to inhibit growth of cell microalgae carried out microscopically by looking at changes in morphology through color changes of chloroplast within the time duration of $0,3,5,7,10,15$ days and also made observations amount of mortality cell microalgae duration time 0,3 , and 15 days. Parameter morphological changes done by observation of the color change decay chloroplast using a microscope with a magnification of 1000x. While counting the cell density, cell mortality microalgae can be done using the Improved Neubauer counting chamber method. Variations in the concentration of essential oil are 10\%,20\%,30\%,40\% and 50\%. Based on the test results showed that the four essential oils can 
inhibit the growth of microalgae cells with the effectiveness of Ginger $>$ Nutmeg $>$ Patchouli $>$ Cloves. Ginger essential oil concentration of $20 \%$ with a testing time 15 days showed inhibition of the most effective in inhibiting growth cell microalgae with cell mortality $63.31 \%$.

Keywords : Microalgae, Lichen, Essentuial Oils

\section{Pendahuluan}

Cagar Budaya berbahan batu banyak ditemui di Indonesia dalam berbagai macam jenis, bentuk dan ukuran. Beberapa contohnya adalah:candi, menhir, arca, dakon, dan lain-lain. Cagar Budaya yang terletak di luar ruangan sangat rentan terhadap kerusakan dan pelapukan, karena faktor internal yang berupa material penyusun benda itu sendiri maupun faktor eksternal, yaitu lingkungan di sekitar benda tersebut berada.

Jenis kerusakan dan pelapukan terdiri dari fisis, kimia dan biologi. Pelapukan yang terjadi pada Cagar Budaya berbahan batu akibat faktor biologi disebabkan oleh pertumbuhan ganggang/alga, lumut/moss dan lumut kerak/ lichen.

Salah satu upaya untuk menangani lumut kerak dilakukan dengan menggunakan bahan kimia AC 322. Komponen AC 322 terdiri dari amonium bikarbonat, sodium bikarbonat, disodium salt EDTA, CMC, Arkopal dan air.

Bahan AC 322 sampai saat ini merupakan satu-satunya bahan yang digunakan dalam menangani permasalahan lumut kerak yang tumbuh pada permukaan batu. Oleh sebab itu, upaya pengembangan bahan konservan sebagai bahan pengganti AC 322 perlu untuk dilakukan.

Balai Konservasi Borobudur mulai mengembangkan metode serta teknik konservasi berbasis penggunaan bahan tradisional. Untuk menangani permasalahan lumut kerak dilakukan dengan menggunakan minyak atsiri. Minyak atsiri dapat berguna sebagai pestisida nabati, yang dapat mengurangi pencemaran terhadap lingkunganserta harganya relatif lebih murah apabila dibandingkan dengan pestisida kimia sintetik(Sudarmo, 2005). Minyak atsiri banyak tersedia dialam dan telah banyak digunakan sebagai bahan antijamur.

Pada akhir tahun 2014 sampai awal tahun 2015

Balai Konservasi Borobudur bekerjasama dengan Universitas Islam Indonesia untuk melakukan penelitian dalam upaya penanganan lumut kerak. Minyak atsiri yang digunakan dalam penelitian adalah minyak atsiri cengkeh, minyak biji pala dan minyak serai wangi. Hasil penelitian menunjukkan bahwa minyak atsiri cengkeh, biji pala dan sereh wangi pada skala laboratorium dapat menghambat pertumbuhan jamur Penicillium sp dari lumut kerak yang terdapat pada Cagar Budaya berbahan batu andesit.

Pada tahun 2015 dilakukan kajian terhadap penggunaan minyak atsiri untuk menghambat pertumbuhan lumut kerak pada Cagar Budaya berbahan batu andesit. Lumut kerak merupakan simbiosis antara jamur/fungi dan ganggang/alga. Ruang lingkup kajian tahun 2015 dibatasi pada percobaan minyak atsiri terhadap daya hambat pertumbuhan jamur penyusun lumut kerak. Minyak atsiri yang digunakan dalam kajian tahap I ini adalah minyak atsiri nilam, temulawak, dan terpentin; dengan konsentrasi $10 \%, 20 \%, 30 \%, 40 \%$ dan $50 \%$. Metode yang digunakanuntuk mengetahui efektifitas minyak atsiri dalam menghambat pertumbuhan jamur pada lumut kerak adalah difusi kertas saring dengan melihat diameter zona hambat pertumbuhan jamur. Berdasarkan hasil kajian, salah satu jenis jamur penyusun lumut kerak pada permukaan batu Candi Borobudur adalah jamur Penicillium sp. Minyak atsiri nilam, temulawak, terpentin dalam percobaan skala laboratorium dapat menghambat pertumbuhan jamur Penicillium spdari lumut kerak. Tingkat efektifitas berdasarkan diameter zona hambat pertumbuhan jamur adalah minyak atsiri terpentin, nilam dan temulawak. Hasil pengujian pada skala lapangan menunjukkan bahwa minyak atsiri nilam, temulawak dan terpentin efektif dapat menghambat pertumbuhan lumut kerak. Pengamatan visual secara langsung maupun melalui foto menunjukkan terjadinya perubahan warna lumut kerak dari hijau menjadi kecoklatan, yang menandakan hilangnya kloroplas pada klorofil.

Pada tahun 2016 dilakukan kajian lanjutan untuk mengetahui daya hambat minyak atsiri terhadap pertumbuhan alga penyusun lumut kerak. Tujuan dari kajian ini adalah memperoleh bahan yang paling efektif 
menghambat pertumbuhan mikroalga penyusun lumut kerak pada Cagar Budaya berbahan batu andesit. Minyak atsiri yang digunakan yaitu: minyak atsiri cengkeh, biji pala, temulawak dan nilam.

\section{Metodologi}

Mikroorganisme yang digunakan dalam penelitian ini adalah mikroalga yang berasal dari sampel lumut kerak pada batu lepas Candi Borobudur. Lumut kerak merupakan simbiosis antara jamur dan alga. Untuk memisahkan kedua komponen tersebut dilakukan dengan cara disentrifuse dengan kecepatan $350 \mathrm{rpm}$ selama 30 menit. Hasil pemisahan pada bagian bawah diperkirakan merupakan mikroalga, sedangkan bagian atas adalah jamur.

Medium yang digunakan untuk biakan mikroalga adalah medium BG 11. Medium BG 11 merupakan medium yang digunakan untuk biakan cyanobacteria, dengan komposisi sebagai berikut: $\mathrm{NaNO}_{3}(1,5$ gram), $\mathrm{K}_{2} \mathrm{HPO}_{4} 3 \mathrm{H}_{2} \mathrm{O}(0,04 \mathrm{gram}), \mathrm{MgSO}_{4} \cdot 7 \mathrm{H}_{2} \mathrm{O}(0,075 \mathrm{gram})$, $\mathrm{CaCl}_{2} \cdot 2 \mathrm{H}_{2} \mathrm{O}$ (0,036 gram), Citric Acid(0,006 gram), Ferric ammonium citrate(0,006 gram), EDTA( $\left.\mathrm{Na}_{2} \mathrm{MgSalt}\right)$ 0,001 gram, $\mathrm{Na}_{2} \mathrm{CO}_{3}(0,02$ gram), Trace Metal Solution $(1,0$ $\mathrm{ml} /$ liter), dan aquadest. Trace metal solution terdiri dari $\mathrm{H}_{3} \mathrm{BO}_{3}, \mathrm{MnCl}_{2} \cdot 4 \mathrm{H}_{2} \mathrm{O}, \mathrm{ZnSO}_{4} \cdot 7 \mathrm{H}_{2} \mathrm{O}, \mathrm{Na}_{2} \mathrm{Mo}_{4} \cdot 2 \mathrm{H}_{2} \mathrm{O}$, $\mathrm{CuSO}_{4} \cdot 5 \mathrm{H}_{2} \mathrm{O}$ dan $\mathrm{Co}\left(\mathrm{NO}_{3}\right)_{2} \cdot 6 \mathrm{H}_{2} \mathrm{O}$

Bahan pengujian yang digunakan adalah minyak atsiri nilam, temulawak, cengkeh dan pala, yang dilarutkan dalam etanol. Bahan kimia sebagai pendukung kajian antara lain adalah alkohol $70 \%$ untuk sterilisasi peralatan, spiritus, korek api, kertas $\mathrm{pH}$ universal 1-14. Peralatan

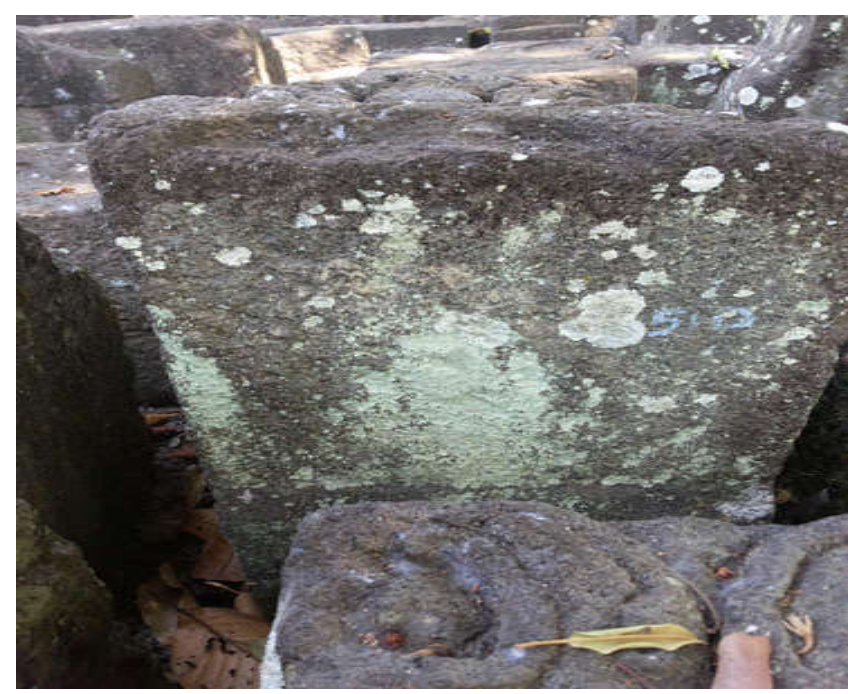

Gambar 1. Lumut kerak pada permukaan batu candi yang digunakan selama kajian meliputi alat gelas dan alat penguji. Alat gelas yang digunakan berupa erlenmeyer250 $\mathrm{ml}$, labu takar $(10 \mathrm{ml}, 500 \mathrm{ml})$ pipet tetes, pipet gondok (1 $\mathrm{ml}, 2 \mathrm{ml}, 5 \mathrm{ml}, 9 \mathrm{ml}$ ), autoklaf, preparat kaca, mikroskop, oven, timbangan, bunsen, hemositometer.

Perlakuan diberikan pada mikroalga selama 15 hari dengan variasi pengamatan 0 hari, 3 hari, 5 hari, 7 hari, 10 hari dan 15 hari. Bahan uji yang digunakan adalah minyak atsiri nilam, temulawak, cengkeh dan pala dengan konsentrasi masing-masing adalah 10\%, 20\%, 30\%, 40\%, dan 50\%. Pengujian dilakukan sebanyak 20 perlakuan setiap variasi hari.

Pengujian efektifitas minyak atsiri untuk menghambat pertumbuhan mikroalga dilakukan secara mikroskopis dengan melihat perubahan morfologi perubahan warna kloroplas dan pengamatan jumlah mortalitas sel mikroalga. Pengamatan warna kloroplas sel mikroalga dilakukan secara mikroskopis selama 0 hari, 3 hari, 5 hari, 7 hari, 10 hari dan 15 hari.

Pengamatan dilakukan dengan mengambil mikroalga dalam larutan uji kemudian diletakkan pada permukaan preparat kaca untuk selanjutnya diamati secara mikroskopis dengan perbesaran 1000x. Skoring dilakukan terhadap warna kloroplas sel mikroalga untuk mempermudah intepretasidata. Skor yang digunakan adalah angka $1-5$, yang menunjukkan kandungan kloroplas dalam mikroalga. Semakin sedikit kandungan kloroplas, maka warna hijau semakin menghilang dan skor yang dimiliki semakin makin kecil.

Penghitungan kerapatan sel, viabilitas sel, dan mortalitas sel mikroalga dilakukan dengan menggunakan metode kamar hitung Improved Neubauer. Pengamatan secara mikroskopis dilakukan selama 0, 3 dan 15 hari. Data jumlah sel digunakan untuk menghitung jumlah sel keseluruhan, yang terdiri dari jumlah sel hidup dan jumlah sel mati. Sel yang dihitung adalah sel yang berada di 4 kotak besar yang terletak disudut luar kamar Improved Neubauer dengan tanda W (White). Masing-masing kotak tersebut memiliki volume 1,0 $\mathrm{mm}^{3}$. Menurut Ali(2001:7), kerapatan sel dalam $1,0 \mathrm{ml}$ sampel dihitung dengan rumus $\mathrm{k}=\mathrm{n} \times \mathrm{x} \times 2500$, dengan $\mathrm{k}=$ kerapatan sel (sel. $\left.\mathrm{mL}^{-1}\right), \mathrm{n}=$ jumlah total sel individu pada keempat kotak kamar hitung, dan $\mathrm{p}$ adalah tingkat pengenceran yang digunakan. Penghitungan dilakukan sebanyak 2 ulangan setiap perlakuan. 
Tabel 1. Rancangan Percobaan

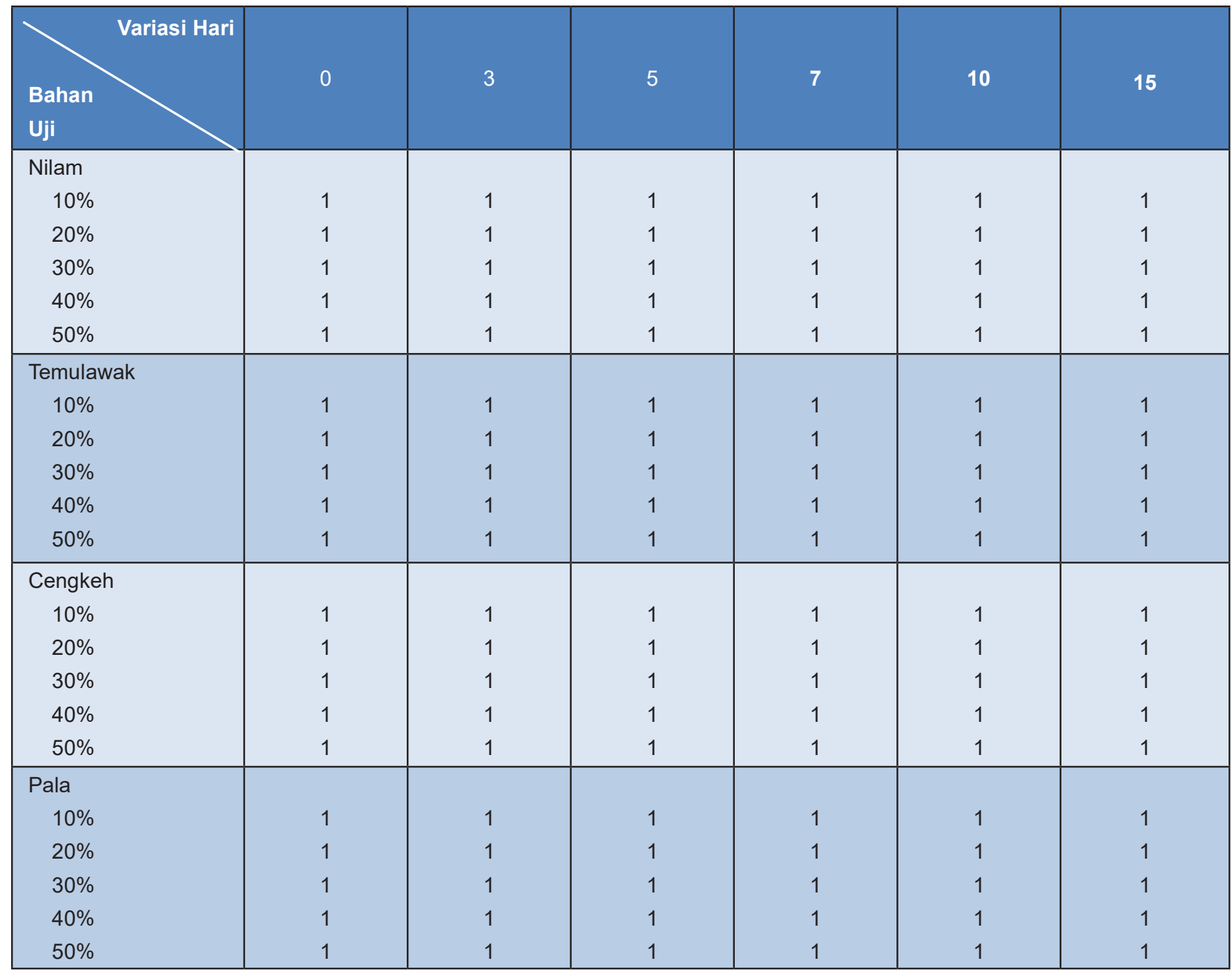

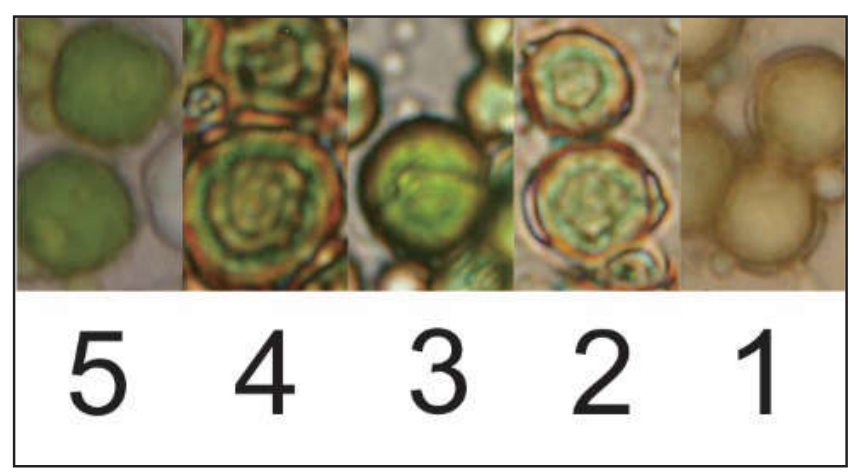

Gambar 2. Skoring kandungan kloroplas

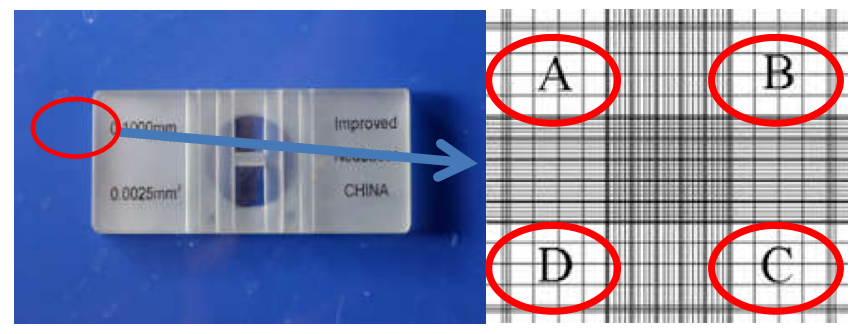

Gambar 3. Penghitungan sel metode kamar hitung Improved Neubauer
Hasil perhitungan diperoleh data berupa jumlah kerapatan sel total yang terdiri dari jumlah kerapatan sel hidup dan jumlah kerapatan sel mati.Untuk menghitung Mortalitas atau jumlah sel mati maka digunakan rumus sebagai berikut:

\section{$\%$ Mortalitas $=\frac{\text { (Jumlah Kerapatan Sel mati) }}{\text { Jumlah Kerapatan Sel Total) }} \times 100 \%$}

Analisis data selanjutnya dilakukan secara kualitatif dan kuantitatif. Analisis data kualitatif meliputi pengamatan mikroskopik sel, yaitu perubahan warna kloroplas sel mikroalga. Analisis data kuantitatif meliputi penghitungan jumlah sel yang terdiri dari jumlah sel hidup dan jumlah sel mati untuk membuat kurva mortalitas mikroalga selama percobaan.

\section{Pembahasan}

\section{Pengujian Efektifitas Nilam}

Hasil perubahan warna kloroplas yang diamati 
secara mikroskopis dengan perbesaran $1000 \mathrm{x}$ setelah perlakuan minyak atsiri nilam berdasarkan skor warna adalah sebagai berikut:

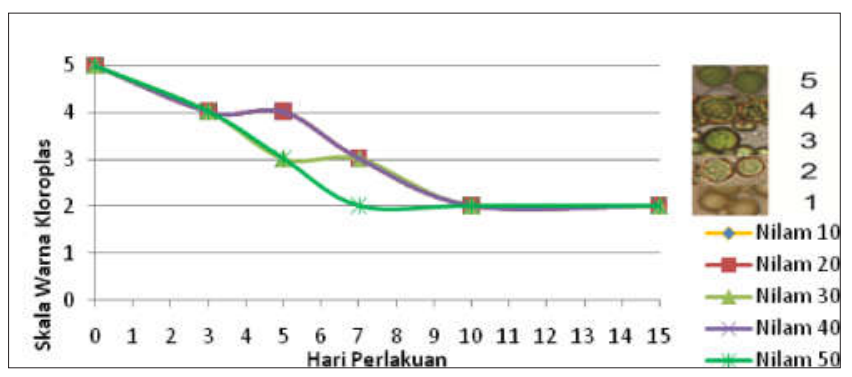

Grafik 1. Skala Warna Kloroplas Mikroalga Setelah Perlakuan Minyak Atsiri Nilam

Berdasarkan grafik di atas terlihat bahwa terjadi perubahan warna kloroplas pada 0 hari sampai perlakuan 15 hari, akan tetapi tidak terlalu signifikan. Terlihat pada konsentrasi 10, 20, 30, 40 dan $50 \%$, pada hari 0 sampai hari 15 percobaan penurunan warna dari skala 5 hingga skala 2, kloroplas masih terlihat berwarna hijau. Variasi konsentrasi juga tidak menunjukkan perbedaan yang nyata, semakin besar konsentrasi tidak berpengaruh terhadap tingkat peluruhan warna kloroplas.

\section{Pengujian Efektifitas Temulawak}

Hasil perubahan warna kloroplas yang diamati secara mikroskopis dengan perbesaran 1000x setelah perlakuan minyak atsiri temulawak berdasarkan skor warna adalah sebagai berikut:

Berdasarkan grafik di atas terlihat bahwa terdapat perubahan warna kloroplas yang signifikan pada 0 hari sampai perlakuan 15 hari. Terlihat pada konsentrasi 10, 20, 30, 40 dan $50 \%$, pada hari 0 sampai hari 15 percobaan terjadi penurunan warna dari skala 5 hingga skala 1, kloroplas sudah mengalami peluruhan warna

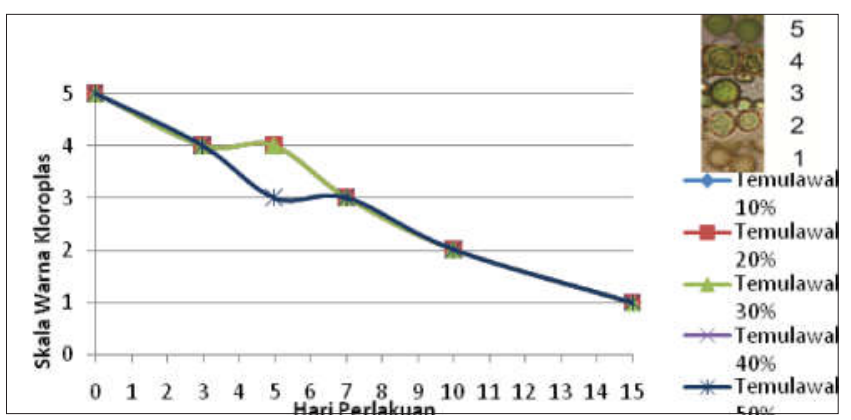

Grafik 2. Skala Warna Kloroplas Mikroalga Setelah Perlakuan Minyak Atsiri Temulawak menjadi kuning kecoklatan. Variasi konsentrasi 10 - 50\% menunjukkan pola perubahan yang sama dari hari 0 sampai 15. Temulawak konsentrasi 10\% percobaan selama 15 hari sudah mampu meluruhkan warna kloroplas.

\section{Pengujian Efektifitas Cengkeh}

Hasil perubahan warna kloroplas yang diamati secara mikroskopis dengan perbesaran 1000x setelah perlakuan minyak atsiri cengkeh berdasarkan skor warna adalah sebagai berikut:

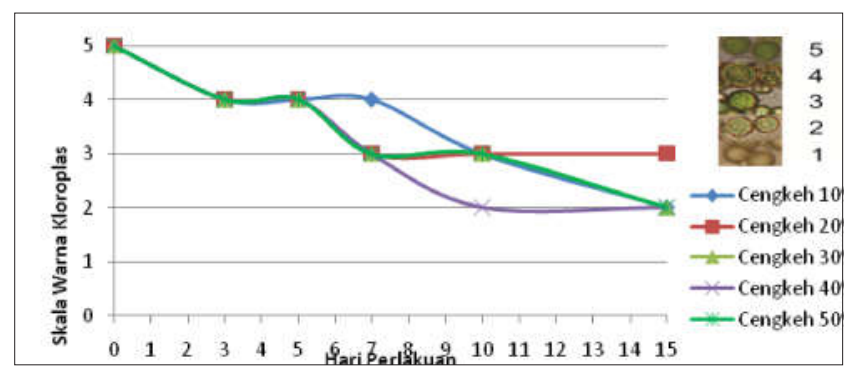

Grafik 3. Skala Warna Kloroplas Mikroalga Setelah Perlakuan Minyak Atsiri Cengkeh

Berdasarkan grafik di atas terlihat bahwa terjadi perubahan warna kloroplas pada 0 hari sampai perlakuan 15 hari akan tetapi tidak terlalu signifikan. Terlihat pada konsentrasi 10, 30, 40 dan $50 \%$. Pada hari 15 percobaan terjadi penurunan warna dari skala 5 hingga skala 2 , dan konsentrasi 20\% kloroplas masih terlihat berwarna hijau. Variasi konsentrasi juga tidak menunjukkan perbedaan yang nyata, semakin besar konsentrasi tidak berpengaruh terhadap tingkat peluruhan warna kloroplas.

\section{Pengujian Efektifitas Pala}

Hasil perubahan warna kloroplas yang diamati secara mikroskopis dengan perbesaran 1000x setelah perlakuan minyak atsiri pala berdasarkan skor warna adalah sebagai berikut:

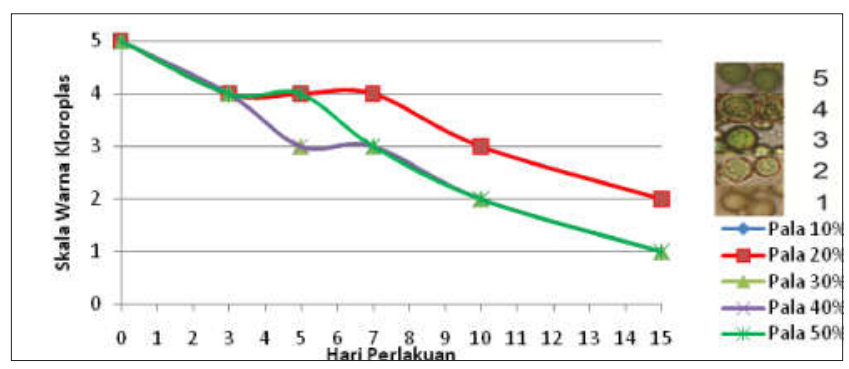

Grafik 4. Skala Warna Kloroplas Mikroalga Setelah Perlakuan Minyak Atsiri Pala 
Berdasarkan grafik di atas terlihat bahwa terdapat perubahan warna kloroplas yang signifikan pada 0 hari sampai perlakuan 15 hari. Terlihat pada konsentrasi 10, 30, 40 dan $50 \%$. Pada hari 15 percobaan penurunan warna terjadi dari skala 5 hingga skala 1, kloroplas sudah mengalami peluruhan warna menjadi kuning kecoklatan. Sedangkan konsentrasi 20\% penurunan warna terjadi dari skala 5 hingga skala 2, kloroplas masih terlihat warna hijau. Variasi konsentrasi juga tidak menunjukkan perbedaan yang nyata, semakin besar konsentrasi tidak berpengaruh terhadap tingkat peluruhan warna kloroplas.

\section{Pengujian Minyak Atsiri untuk menghambat} pertumbuhan sel mikroalga berdasarkan mortalitas sel

Pengujian dilakukan dengan cara menambahkan bahan uji minyak atsiri ke dalam kultur biakan mikroalga kemudian dilakukan pengamatan secara mikroskopis tahap selanjutnya perhitungan jumlah sel hidup, selmati dan tingkat hidup mikroalga setelah perlakuan dengan variasi waktu 0 hari, 3 hari, dan 15 hari. Perhitungan jumlah sel hidup, jumlah sel mati dan jumlah sel total mikroalga menggunakan hemositometer kemudian dihitung dengan sel kalkulator. Adapun variasi konsentrasi masing-masing minyak atsiri adalah 10\%, 20\%, 30\%, 40\%, dan 50\%. Parameter pengujian efektifitas minyak atsiri terhadap perubahan morfologi mikroalga secara mikroskopis berdasarkan pada mortalitas sel mikroalga.

\section{Mortalitas Sel Mikroalga setelah Perlakuan Minyak Atsiri Nilam}

Perhitungan mortalitas sel mikroalga setelah perlakuan 0 hari, 3 hari, dan 15 hari menggunakan hemositometer kemudian dihitung dengan sel kalkulator. Berikut ini disajikan hasil perhitungan mortalitas sel mikroalga dalam grafik

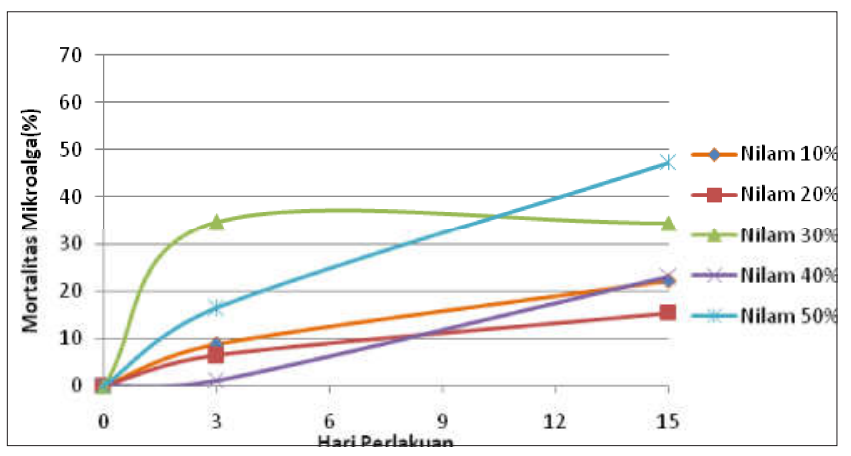

Grafik 5. Mortalitas Sel Mikroalga Setelah Perlakuan Minyak Atsiri Nilam
Berdasarkan hasil pengujian mortalitas sel mikroalga dengan menggunakan minyak atsiri nilam, dari grafik diatas hasil menunjukkan terdapat kenaikan jumlah mortalitas dari hari 0 perlakuan, 3 hari perlakuan dan 15 hari perlakuan. Mortalitas sel mikroalga terendah pada 15 hari perlakuan sebesar 15,38\% pada pengujian bahan nilam konsentrasi 20\%, sedangkan mortalitas sel mikroalga terbesar sebesar $47,37 \%$ pada pengujian nilam konsentrasi 50\%. Pengujian mortalitas sel mikroalga dengan menggunakan minyak atsiri nilam pada berbagai variasi konsentrasi tidak menunjukkan pengaruh yang signifikan. Hal ini diperkuat dengan uji statistik korelasi Pearson, pengujian variasi konsentrasi terhadap mortalitas sel mikroalgae pada 15 hari perlakuan, signifikansi sebesar 0,082 > 0,05, dapat diartikan bahwa variasi konsentrasi tidak berhubungan dengan mortalitas. Nilai korelasi Pearson sebesar 0,728, nilai kekuatan korelasi kuat.

\section{Mortalitas Sel Mikroalga setelah Perlakuan Minyak Atsiri Temulawak}

Perhitungan mortalitas sel mikroalga setelah perlakuan 0 hari, 3 hari, dan 15 hari menggunakan hemositometer kemudian dihitung dengan sel kalkulator. Berikut ini disajikan hasil perhitungan mortalitas sel mikroalga dalam grafik

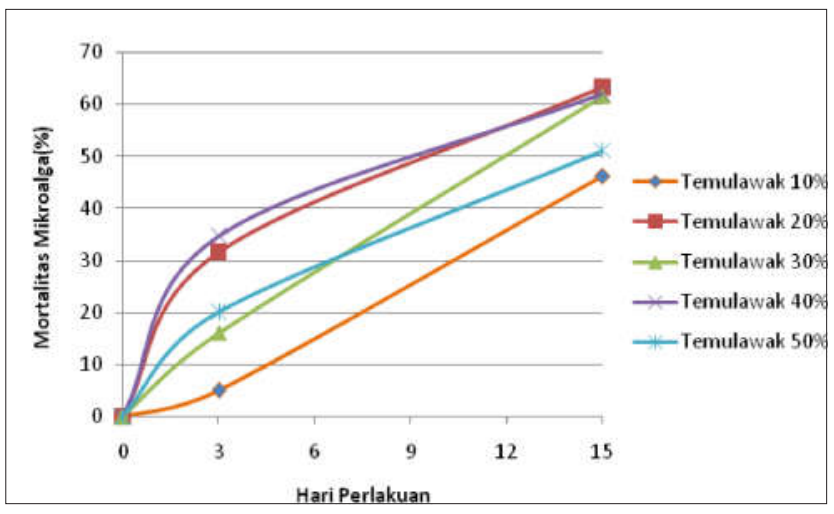

Grafik 6. Mortalitas Sel Mikroalga Setelah Perlakuan Minyak Atsiri Temulawak

Berdasarkan data hasil pengujian mortalitas sel mikroalga dengan menggunakan minyak atsiri temulawak menunjukkan terdapat kenaikan jumlah mortalitas dari hari 0 perlakuan, 3 hari perlakuan dan 15 hari perlakuan. Mortalitas sel mikroalga terendah pada 15 hari perlakuan sebesar 46,24\% pada pengujian bahan temulawak konsentrasi 10\% sedangkan mortalitas 
sel mikroalga terbesar sebesar $62 \%$ pada pengujian temulawak konsentrasi 20\%. Pengujian mortalitas sel mikroalga dengan menggunakan minyak atsiri temulawak pada berbagai variasi konsentrasi tidak menunjukkan pengaruh yang signifikan. Hal ini diperkuat dengan uji statistik korelasi Pearson, pengujian variasi konsentrasi terhadap mortalitas sel mikroalga pada 15 hari perlakuan, signifikansinya sebesar 0,388 >0,05; sehingga dapat diartikan bahwa variasi konsentrasi tidak berhubungan dengan mortalitas. Nilai korelasi Pearson sebesar 0,177 menunjukkan nilai kekuatan korelasi sangat lemah.

\section{Mortalitas Sel Mikroalga setelah Perlakuan Minyak Atsiri Cengkeh}

Perhitungan mortalitas sel mikroalga setelah perlakuan 0 hari, 3 hari, dan 15 hari menggunakan hemositometer kemudian dihitung dengan sel kalkulator. Berikut ini disajikan hasil perhitungan mortalitas sel mikroalga dalam grafik

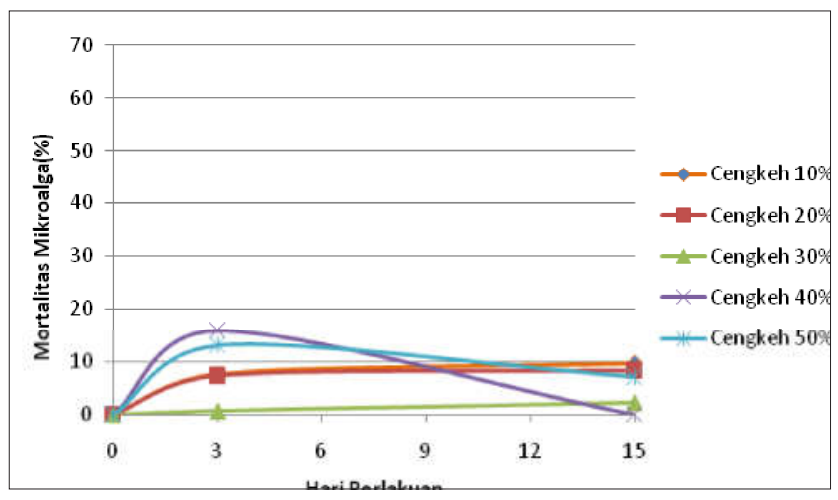

Grafik 7. Mortalitas Sel Mikroalga Setelah Perlakuan Minyak Atsiri Cengkeh

Berdasarkan data hasil pengujian mortalitas sel mikroalga dengan menggunakan minyak atsiri cengkeh menunjukkan terdapat kenaikan jumlah mortalitas dari hari 0 perlakuan, 3 hari perlakuan. Perlakuan 15 hari menunjukkan pola yang stagnan. Mortalitas sel mikroalga terendah pada 15 hariperlakuan sebesar $0 \%$ pada pengujian bahan cengkeh konsentrasi 40\%, sedangkan mortalitas sel mikroalga terbesar sebesar 9,56\% pada pengujian cengkeh konsentrasi $10 \%$. Pengujian mortalitas sel mikroalga dengan menggunakan minyak atsiri cengkeh berbagai variasi konsentrasi tidak menunjukkan pengaruh yang signifikan. Hal ini diperkuat dengan uji statistik korelasi Pearson, pengujian variasi konsentrasi terhadap mortalitas sel mikroalgae pada 15 hari perlakuan, signifikansinya sebesar 0,194 > 0,05; yang dapat diartikan bahwa variasi konsentrasi tidak berhubungan dengan mortalitas. Nilai korelasi Pearson sebesar 0,502 menunjukkan nilai kekuatan korelasi sedang.

\section{Mortalitas Sel Mikroalga setelah Perlakuan Minyak Atsiri Pala}

Perhitungan mortalitas sel mikroalga setelah perlakuan 0 hari, 3 hari, dan 15 hari menggunakan hemositometer kemudian dihitung dengan sel kalkulator. Berikut ini disajikan hasil perhitungan mortalitas sel mikroalga dalam grafik di bawah.

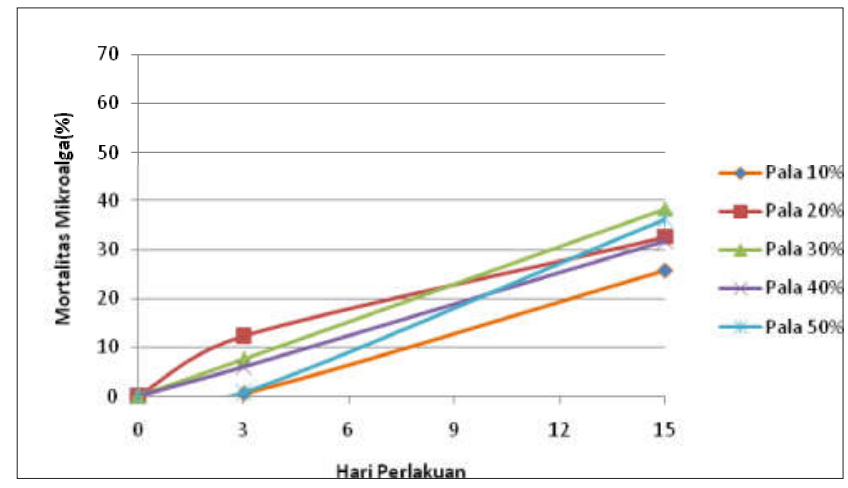

Grafik 8. Mortalitas Sel Mikroalga Setelah Perlakuan Minyak Atsiri Pala

Berdasarkan data hasil pengujian mortalitas sel mikroalga dengan menggunakan minyak atsiri pala menunjukkan terdapat kenaikan jumlah mortalitas dari hari 0 perlakuan, 3 hari perlakuan dan 15 hari perlakuan. Mortalitas sel mikroalga terendah pada 15 hari perlakuan sebesar 25,66\% pada pengujian bahan minyak atsiri pala konsentrasi 10\%, sedangkan mortalitas sel mikroalga terbesar sebesar 36,17\% pada pengujian temulawak dengan konsentrasi 50\%. Pengujian mortalitas sel mikroalga menggunakan minyak atsiri pala pada berbagai variasi konsentrasi tidak menunjukkan pengaruh yang signifikan. Hal ini diperkuat dengan uji statistik korelasi Pearson, pengujian variasi konsentrasi terhadap mortalitas sel mikroalgae pada 15 hari perlakuan, signifikansinya sebesar 0,155>0,05 yang dapat diartikan bahwa variasi konsentrasi tidak berhubungan dengan mortalitas. Nilai korelasi Pearson sebesar 0,655 menunjukkan nilai kekuatan korelasi kuat.

Perbandingan Mortalitas Sel Mikroalga setelah Perlakuan Minyak Atsiri Nilam, Temulawak, Cengkeh dan Pala

Pengujian menggunakan 4 jenis minyak atsiri yang berbeda bertujuan untuk mengetahui minyak atsiri 
yang paling efektif digunakan sebagai bahan penghambat pertumbuhan sel mikroalga berdasarkan mortalitas sel mikroalga. Keempat jenis minyak atsiri dibandingkan dalam konsentrasi yang sama dengan waktu percobaan selama 15 hari.

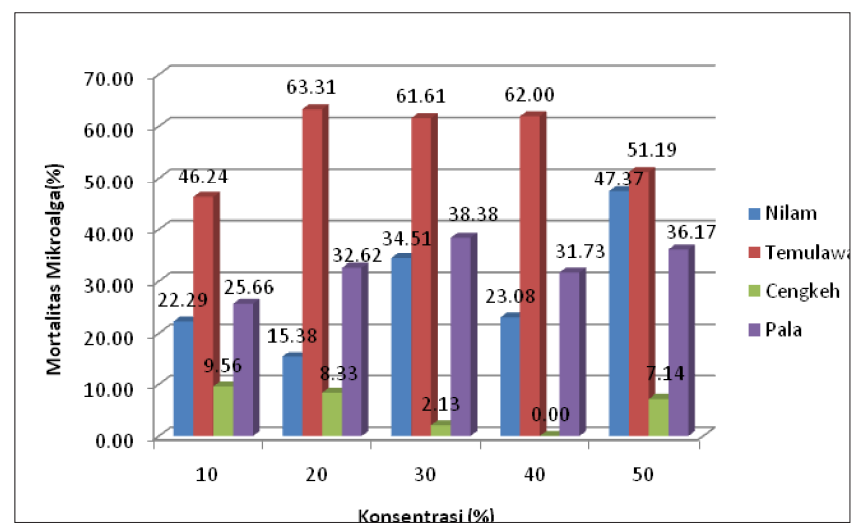

Grafik 9. Mortalitas Sel Mikroalga setelah 15 hari Perlakuan Minyak Atsiri berbagai Konsentrasi

Berdasarkan grafik di atas, terdapat pola kenaikan mortalitas sel pada perlakuan 0 hari, 3 hari dan 5 hari pada semua variasi percobaan baik variasi jenis minyak maupun jenis konsentrasi. Pengujian minyak atsiri temulawak sebagai bahan penghambat pertumbuhan dilihat dari mortalitas sel mikroalga, terlihat paling tinggi mortalitasnya pada berbagai macam konsentrasi 10\% sampai 50\% dibandingkan dengan minyak atsiri yang lain. Minyak atsiri temulawak 20\% menunjukkan daya penghambatan yang besar pada hari15 perngujian, yaitu sebesar63,31\%.

Efektivitas Minyak Atsiri Nilam, Temuawak, Cengkeh dan Pala dalam menghambat Pertumbuhan Jamur dan Mikroalga

Berdasarkan hasil penelitian tahun 2014 sampai tahun 2015 mengenai daya hambat pertumbuhan jamur Penicillium sp dengan menggunakan 4 jenis minyak atsiri pada konsentrasi $10 \%$, minyak atsiri nilam dapat menghambat pertumbuhan jamur dengan diameter zona hambat $20 \mathrm{~mm}$ (sumber data Kajian Minyak. Atsiri Tahap I), minyak atsiri temulawak dapat menghambat pertumbuhan jamur dengan diameter zona hambat $14 \mathrm{~mm}$ (sumber data Kajian Minyak. Atsiri Tahap I), minyak atsiri cengkeh dapat menghambat pertumbuhan jamur dengan diameter zona hambat $12 \mathrm{~mm}$ (Yeksti, 2015), minyak atsiri pala dapat menghambat pertumbuhan jamur dengan diameter zona hambat 7,5 mm(Rina, 2015). Berdasarkan hasil pengujian minyak atsiri dalam menghambat pertumbuhan jamur Penicillium sp, minyak atsiri yang memiliki zona penghambatan yang besar secara berturut-turut adalah sebagai berikut: nilam, temulawak, cengkeh, dan pala.

Pembiakan alga dilakukan dalam medium BG 11 dan diamati pertumbuhannya. Dilakukan peremajaan stok sub kultur alga dengan mengganti medium BG 11 setiap 1 bulan sekali. Berdasarkan hasil pengamatan secara mikroskopis dalam biakan terdapat multispesies, sehingga belum dilakukan identifikasi jenis mikroalga secara keseluruhan. Pada kajian tahap 1 tahun 2015 telah dilakukan identifikasi salah satu jenis mikroalga.Hasil identifikasi menunjukkan alga termasuk jenis Chrococcus yang memiliki ciri bersel satu, berbentuk bulat, tidak berkoloni dan termasuk dalam Cyanobacteria. Pengujian efektifitas minyak atsiri nilam, temulawak, cengkeh dan pala dalam menghambat pertumbuhan sel mikroalga dilakukan pada kajian tahap II. Berdasarkan hasil pengujian diperoleh hasil bahwa keempat minyak atsiri dapat menghambat pertumbuhan sel mikroalga dengan tingkat keefektifitasan berturut-turut sebagai berikut: minyak atsiri temulawak, pala, nilam, dan cengkeh.

Berdasarkan tabel diatas, minyak atsiri nilam, temulawak, dan pala dapat menghambat pertumbuhan lichen dengan menghambat pertumbuhan jamur dan alga. Sedangkan minyak atsiri cengkeh dapat menghambat pertumbuhan pertumbuhan jamur saja, sedangkan pertumbuhan sel mikroalga tidak dapat dihambat pertumbuhannya.

\section{Pembahasan}

Penggunaan minyak atsiri sebagai bahan penghambat pertumbuhan sel mikroalga sudah banyak dilakukan penelitian. Penelitian inijuga melakukan pengujian efektfitas minyak atsiri dalam menghambat pertumbuhan sel mikroalga. Parameter pengujian efektifitas minyak atsiri dalam menghambat pertumbuhan sel mikroalga berdasarkan pada peluruhan atau penurunan warna kloroplas sel kemudian dilakukan perhitungan jumlah kerapatan sel, kerapatan sel hidup, dan kerapatan sel mati. Berdasarkan jumlah kerapatan sel mati maka dapat dihitung mortalitas sel mikroalga.

Sel mikroalga memiliki kloroplasyang mengandung pigmen atau zat warna. Pigmen dalam 


\section{Tabel 2. Penghambatan Pertumbuhan Lichen Setelah Pengujian Minyak Atsiri}

\begin{tabular}{|c|c|c|}
\hline \multirow{2}{*}{$\begin{array}{c}\text { Bahan Uji } \\
\text { Minyak Atsiri }\end{array}$} & \multicolumn{2}{|c|}{ Daya hambat Pertumbuhan Lichen } \\
\hline & Jamur Penyusun Lichen & Mikroalgae Penyusun Lichen \\
\hline Nilam & + & + \\
\hline Temulawak & + & + \\
\hline Cengkeh & + & - \\
\hline Pala & + & + \\
\hline
\end{tabular}

kloroplas berfungsi untuk menyerap energi cahaya matahari yang berguna dalam proses fotosintesis. Pigmen utama yang terdapat dalam kloroplas adalah klorofil yang berwarna hijau (Bidigare, 1989:177). Parameter pengujian efektifitas minyak atsiri dalam menghambat pertumbuhan sel mikroalga berdasarkan pada peluruhan atau penurunan warna kloroplas sel. Setiap perubahan warna kloroplas dilakukan penilaian skala warna mulai dari 5, 4, 3, 2, dan 1, warna kloroplas mengalami penurunan dari hijau menuju kuning kecoklatan maka skala warna semakin menurun. Durasi pengamatan peluruhan warna kloroplas dilakukan selama 15 hari dengan variasi hari $0,3,5,7,10$ dan 15 hari. Hasil percobaan menggunakan 4 jenis minyak atsiri nilam, temulawak, cengkeh dan pala pada variasi konsentrasi 10\%- 50\% dalam waktu 0, 3, 5, 7, 10 dan 15 hari perlakuan menunjukkan hasil yang sama, yaitu terjadi peluruhan warna kloroplas, ditandai dengan semakin hilangnya warna hijau menuju ke arah kuning kecoklatan. Peluruhan warna kloroplas secara tidak langsung akan menggangu pertumbuhan sel mikroalga dalam proses fotosintesis.

Penentukan efektifitas minyak atsiri dalam menghambat pertumbuhan sel mikroalga secara kuantitatif dapat dilihat dari mortalitas sel mikroalga. Mortalitas sel mikroalga diperoleh dari perhitungan jumlah sel hidup dan sel mati. Pengamatan jumlah kerapatan sel hidup dan kerapatan sel mati dilakukan secara mikroskopis dan dihitung menggunakan metode kamar hitung. Mortalitas diperoleh dari hasil perhitungan menggunakan perbandingan jumlah kerapatan sel mati dengan jumlah kerapatan sel keseluruhan. Durasi pengamatan mortalitas sel mikroalga dilakukan selama
15 hari dengan variasi hari 0, 3, dan 15 hari. Hasil percobaan menunjukkan bahwa hanya 3 jenis minyak yang menyebabkan terjadinya kenaikan mortalitas sel mikroalga selama 15 hari perlakuan, yaitu temulawak, nilam, dan pala pada variasi konsentrasi 10\%-50\%.

Pengujian terhadap 4 (empat) jenis minyak atsiri menunjukkan bahwa minyak atsiri temulawak dengan konsentrasi 20\% paling efektif digunakan sebagai bahan penghambat pertumbuhan sel mikroalga. Hal ini terlihat dari peluruhan warna kloroplas dan mortalitas sel mikroalga yang tinggi, ditandai dengan adanya skor warna kloroplas pada angka 1 dan mortalitas sebesar 63,31\%. Beberapa minyak atsiri mengandung senyawa monoterpen yang bersifat sebagai antimikroba seperti cymene, sabinen, a-pinen, $\beta$-pinen, sitronellol, geraniol, carvacrol, thymol, farnesol, dan caryopbylenne (Reichling, 2009). Dalam minyak atsiri temulawak dan pala mengandung senyawa pinen yang bersifat antimikroba, sehingga dapat menghambat pertumbuhan sel mikroalga.

\section{Penutup}

\section{Kesimpulan}

Berdasarkan hasil percobaan laboratorium uji efektifitas minyak atsiri terhadap penghambatan pertumbuhan mikroalga lumut kerak pada batuan andesit Candi Borobudur diperoleh kesimpulan sebagai berikut :

1. Lumut kerak/lichenmerupakan simbiosis antara jamur dan alga. Pemisahan kedua komponen tersebut menghasilkan kelompok jamur Penicillium sp. Sedangkan mikroalga belum dapat diidentifikasi karena dalam subkultur terdapat multispesies.

2. Minyak atsiri nilam, temulawak, cengkeh dan pala 
dapat menghambat pertumbuhan sel mikroalga dari lumut kerak. Tingkat keefektifan bahan uji pengamatan secara mikroskopis didasarkan pada peluruhan warna kloroplas selama 15 hari percobaan dengan dilakukan skoring skala warna. Pada percobaan minyak atsiri temulawak dan pala terjadi peluruhan warna dari hijau menjadi kuning kecoklatan dari skala warna 5 menjadi 1. Sedangkan percobaan minyak atsiri cengkeh dan nilam terjadi sedikit peluruhan warna dari hijau tua menjadi hijau muda, skoring peluruhan kloroplas berdasarkan skala warna dari 5 menjadi 3-2.

3. Pengujian minyak atsiri nilam, temulawak, cengkeh dan pala berdasarkan percobaan dapat menghambat pertumbuhan sel mikroalga dari lumut kerak secara mikroskopis dengan metode kamar hitung. Tingkat keefektifan ditinjau dari mortalitas sel mikroalga. Minyak atsiri temulawak merupakan minyak atsiri yang paling efektif

\section{DAFTAR PUSTAKA}

Alexopoulus et all. 1996.Introductory Mycology

Ali NA, Martina W, N Amold, U Lindequist, L Wessjohan. 2008. Essential Oil Composition from Oleogum Resin of Soqotraen Commiphora kua, Rec. Nat. Prod. 2 (3) : 70-75

Asthuti, M.M.M, Simiartha, K, Susila, I.W, Wirya, C.N.A.S, Sudiarta, I.P. 2012. Efikasi minyak atsiri cengkeh(Syzygium Aromaticum .L), Meer \& Perry), Pala(Myristica fragrans Houtt), dan jahe(Zingiber officinale Rosc) terhadap Mortalitas Ulat Bulu Gempinis darifamily Lymantriidae. J.Agric. Sci. And Biotechnol. Vol. 1, No 1. ISSN : 23020-113

Burt, s. 2007. Antibacterial Activity of Essential oils : Potential Application in Food. Ph.d. Thesis. Institute for Risk Assesment Sciences, Divition of Veterinary Medicine, Public Health. Utrecht University

Chakrapani. P, vankatesh K, Singh, B.C.S, Jyothi, B.A. Kumar, P, Amareshwari, P, Rani, A.R. 2013. Phytochemical, Pharmacological Importance of patchouli(Pogostemon cablin(Blanco) Benth) an Aromatic dalam menghambat pertumbuhan sel mikroalga. Sedangkan minyak cengkeh paling tidak efektif dalam menghambat pertumbuhan sel mikroalga.

4. Minyak atsiri temulawak dengan konsentrasi 20\% mampu menghambat pertumbuhan sel mikroalga dengan mortalitas mikroalga sebesar $63,31 \%$.

\section{Saran}

Berdasarkan kajian yang sudah dilakukan, saran yang diajukan dalam rangka penyempurnaan kajian berikutnya adalah :

1. Perlu dicari konsentrasi minimum yang dapat menghambat pertumbuhan sel mikroalga.

2. Perlu dicari metode yang tepat untuk pengujian daya hambat pertumbuhan mikroalga karena dengan metode kamar hitung terdapat banyak kekurangan dalam pengujian sampling secara acak.

Medicinal Plant, Int. J. Pharm. Science, rev. Res, $21(2): 7-12$

Croci, Giorgio.1989.The Conservationand structural Restoration of Architectural Heritage, Computational Mechanics Publication Southmpton, UK and Boston, USA.

Dyah Y. 2015. Uji Efektifitas Minyak Atsiri Cengkeh untuk. Menghambat Pertumbuban Lumut Kerak(Lichenes) pada Cagar Budaya Batu, FMIPA Universitas Islam Indonesia, Yogyakarta.

Doyle, M.P. and Muggall, W.S. 1980. Experimenttal Organic Chemistry. John Wiley \& Sons, New York

Edward G. Bellinger and David V C.Sigee. 2010. Freshwater Algae

Parwata IMOA, P. Fanny SD. Isolasi dan Uji Aktivitas Antibakteri Minyak Atsiri dari Rimpang lengkuas(Alpinia galaga L). Jurnal Kimia, 2008:(2(2): $100-4$

Pelezar, M.J. dan r.D. Ries. 1982. Microbiology. Tata McGraw Hill book Co. Ltd, New Delhi

Prescott, L M, Harley JP, Klern D A. 1999. Microbiology $4^{\text {th }}$ 
ed. The MC Grow Hill, USA

Price, T.D \& Borton, J.H, 2011, An. Introduction to Archeological Chemistry, Springer, New York.

Rahmi, M.J, Adel Z, Yuharmea, 2014. Perbandingan Isolasi Minyak Atsiri daun Nilam(Pogostemon cablin Benth) Metode hidrodistilasi konvensional dan hidrodistilasi Oven Microwave disertai Uji Aktivitas Antimikroba. Jurnal FMIPA Universitas Riau, Volume 1 No 2 Oktober 2014, page 327-334

Rina A. 2015. Uji Efektifitas Minyak. Atsiri Biji Pala(Myristica fragans houtt (untuk. Menghambat Pertumbuban Lumut Kerak(Lichenes) pada Cagar Budaya Batu, FMIPA
Universitas Islam Indonesia, Yogyakarta.

Sastrohamidjojo, H. 2002. Kimia Minyak Atsiri. FMIPA Universitas Gadjah Mada. Yogyakarta

Soesilo, S. 1989. Vademekum Bahan Obat Alam. Jakarta : Departemen Kesehatan Republik Indonesia

Upadhyay, R. K.P, Dwivedi, and S.Ahmad. 2010. Screening of Antibacterial Activity of Six Plant Essential Oils Against Pathogenic Bacterial Strains. Asian J. Of Medical Sciences. 2(3) : 152-158

Wahyuni, Sri, dkk. 2015. "Laporan Hasil Kajian Minyak Atsiri untuk Cagar Budaya Berbahan Batu Tahap I' . Balai Konservasi Borobudur 